\title{
A SWOT Analysis of MOOC on Business English Teaching
}

\author{
Wang Jin-hui ${ }^{1}$ \\ ${ }^{1}$ Shandong Institute of Business and Technology, \\ Shandong, China
}

\begin{abstract}
MOOC has become a common phenomenon in higher education, and researchers are discussing its application in teaching. After a brief introduction of MOOC, business English teaching as well as SWOT analysis method, the method is adopted in the analysis of MOOC in terms of business English teaching. The strength, weakness, opportunity and threat are analyzed respectively. In conclusion, educators should notice the advantages of MOOC despite the disadvantages, and devote to application of MOOC for a better construction of business English discipline.
\end{abstract}

Keywords: MOOC; business English teaching; SWOT analysis

\section{INTRODUCTION}

MOOC, or Massive Open Online Courses, is the online course aimed at online participation and open resources. Except for traditional materials, like videos, reading materials and exercises, MOOC also provides an online forum, which is popular in recent decades, for it emphasizes not only learning and learners, but also the platform on which teachers and students have access to the discussion of some topic.

MOOC is put forward by Dave Cormier and Bryan Alexander in 2008. The name MOOC sheds light on its characteristics: "massive" refers to the large number of learners as well as courses and activities (Masters, 2011); "open", a unique trait of MOOC, refers to the equality of learners regardless of information resource, educational background, learning environment, learning time, and cite; "online" includes not only the method of acquiring materials, but also the cooperation and evaluation of participants.

\section{Business English Teaching}

Business English teaching can be traced back to 16 century. Broadly, business English is concerned with business including economy, management, laws, etc. (Wang Guanfu \& Zhang Haisen, 2011). Hence the aim of business English teaching is to cultivate students with broad horizon, excellent English skills as well as comprehensive business background. In that way, business English major should perform an interdisciplinary study of economics, management, and law so that they are qualified for positions in business, trade, management, finance, etc. (Chen Zhunmin \& Wang Lifei, 2009). The teachers are also required to have interdisciplinary background to maintain English teaching and business teaching. (Liu Fagong, 2009).

\section{SWOT analysis}

A SWOT analysis (or SWOT matrix) is a structured planning method used to evaluate the strengths, weaknesses, opportunities and threats involved in a project or in a business venture. This tool can be carried out for a product, place, industry or person. According to Weihrich (1982), it involves the internal and external factors to identify if they are favorable or unfavorable in achieving the objective of the business venture or project. Internal factors include Strengths and Weakness, and 
external factors include Opportunities and Threats. Among them, Strengths are the characteristics of the business or project that give it an advantage over others; Weaknesses are those placing the business or project at a disadvantage relative to others; Opportunities are elements that the project could exploit to its advantage; Threats are those in the environment that could cause trouble for the business or project.

\section{SWOT Analysis of MOOC on Business English Teaching}

SWOT analysis is originated from the study of marketing, and has been applied to the strategic decision making of industry, entrepreneur and product. With various applications, SWOT analysis in business English teaching is also feasible. The SWOT analysis is conducted to analyze strength, weakness, opportunity and threat of MOOC on business English teaching.

\subsection{Strength}

Open and available resources. MOOC provides the courses from top-ranking universities all over the world, which is beneficial for students' interdisciplinary study. It broads the horizon of the students who are to apply for a second degree. It also makes it possible for the mutual recognition of credits among colleges. Besides, for the teachers, the recourses help to make up for the inadequacy of business background information to those who transfer from language majors.

Versatile and vivid forms. MOOC adopts animations, videos, mini-courses, online tests, RSS and BBS, which are in line with the guidance of business English teaching, to enhance practical abilities.

Process evaluation. Teachers have a comprehensive understanding of students learning schedule, including online time, visits, communication times, learning progress, online test scores, etc. Hence the evaluation will be based on the process rather than final exams.

Pan-learning. Students can study regardless of time and place on mobile devices. They can also break the tasks into fragments for the sake of efficiency and permeability.
Autonomous learning. Students will be free to arrange their own schedules for better understanding of the contents.

\subsection{Weakness}

High costs. the development of the platform calls for great manpower, material resources and financial resources. It is the same with its operation and maintenance. For example, a course requires the cooperation of several teachers: the lecturer needs 100 hours for preparation on average; at least one assistant is needed for online Q\&A, spending 8 hours a week on average (Steve, 2013). The courses of business English are newly designed, so there must be huge investment in the development of the courses.

A lack of business English curriculum. Business English is an interdisciplinary major whose curriculum has not been fully established. Students have to refer to courses from other majors, like English literature, finance and management. Such combination will not contribute to the pertinence of business English major.

Disadvantages of the textbooks. Business textbooks are still faced with problems: unsystematic design, antedated and unpractical articles, ambiguous illustration and a lack of materials, which hinder the development of MOOC (Hu Jun \& Liu Baiyu, 2011).

Misunderstanding by teachers. A number of teachers have a negative attitude, even fear and resistance, towards MOOC. There are also many a teachers who would like to wait and see for they believe there is no correlation between MOOC and their application for higher positions.

The change of teachers' role. Teachers have been transferred from the message sender of traditional courses to the guider and pusher of students' inquisitive study, which may damage the authority and in turn affect students in a limited way.

A lack of self-control by the students. As many as $95 \%$ of the students drop out from the MOOC courses opened by Stanford, MIT and UC Berkeley. In other words, it is impossible to depend merely on students' self-control for the accomplishment of the courses (Meyer, 2012). 


\subsection{Opportunity}

Prospect for a new major. Business English major as an independent major is built up officially in China in 2007, which devotes to the cultivation of interdisciplinary elites. Resources are infusing for a better practice of new teaching methods, which fits for the application of MOOC.

Policy and financial support. In 2013, the Department of Education in China implemented new policies to enhance the financial and technology support so that students all over the country can have access to online resources.

An example set by existing MOOC platforms. In 2013, Peking University and Qsinghua University joined edX. Fudan University and Shanghai Jiao Tong University joined Coursera afterwards. This cooperation will lay a solid foundation for universities in China in later construction of their own MOOC. Meanwhile, the existing platforms are attempting to localize their courses in China. All of the attempts are beneficial to MOOC in China, which will in turn be more friendly to Chinese learners.

\subsection{Threats}

Challenges to traditional classes. When students get used to MOOC which can be arranged according to their own tastes, they will lose interest in traditional teacher-centered classes in large classrooms.

Challenges from top-ranked universities. Students may give up the opportunity to enter a plain university or college, if they manage to get access to courses and even credits from top-ranked universities and colleges from all over the world regardless of time and location.

\section{Conclusion}

MOOC is both opportunity and challenge to business English teaching in China. Educators should neither refuse to recognize it nor regard it as an elixir. The riptide of MOOC force business English teachers to be faced with it, so how to embrace it and take advantage of it for a better construction of the discipline.

\section{References}

[1] Fa-gong Liu. Business English Dicipline in the Development, Foreign Language World, pp10-16, 2009.

[2] Guan-fu Wang \& Hai-sen Zhang, An Inquiry into the Factors Essential to business English Teachers' Competence in the Development of Business English as a Discipline, Foreign Language World, pp15-21, 2011.

[3] Jun Hu \& Bai-yu Liu, Investigation and Assessment Report on Construction of Business English Textbook - Based on the 30 Questionnares Based on College Textbooks in Shandong Province, Journal of Higher Education Finance, pp 53-57, 2011.

[4] K. Masters, "A Brief Guide to Understanding MOOCs," The Internet Journal of Medical Education. 2011.

[5] Weihrich, H. The TOWS Matrix: A Tool for Situational Analysis [J]. Long Range Planning, 1982, 15 (2): 54-66.

[6] Zhun-min Chen, "Developing National Curriculum for BA Program in Business English of China," Foreign Languages in China, pp 4-11+21, 2009.

[7] http://tinyurl.com/cdfvvqy.

[8] http:// chronicle. Com /article/ The-Professors-Behind-the-MOOC/137905/\#id= results. 